\title{
THE EFFECT OF MURATTAL TO RELIEVE DYSMENORRHEA PAIN IN FEMALE STUDENTS
}

\author{
Qanita Chairun Nissa, Neni Nuraeni, Hani Handayani \\ Faculty of Health Science, Nursing Major, Universitas Muhammadiyah Tasikmalaya, Indonesia \\ Correspondence: qchairunnissa@gmail.com, neni.nuraeni@umtas.ac.id, hani.handayani@umtas.ac.id
}

\begin{abstract}
Dysmenorrhea is menstruation pain that would interfere women's activities. Murattal is a nonpharmacological technique that may relieve menstruation pain. The aim of this research was to find the effect of Murattal in relieving dysmenorrhea for female student of SMPN 12 Tasikmalaya. This research used quasi-experiment with pre-posttest and control group design. Respondents were selected using purposive sampling technique. This study involved 15 students in a group treatment and 15 students in a group control used technique purposive sampling. The instrument of this study was Numeric Rating Scale (NRS) Instrument. Respondents listened Murattal Surah Ar-Rahman. Data were analyzed using paired TTest also used. The result found that there was an effect of Murattal to relieve dysmenorrhea pain for female student of SMPN 12 Tasikmalaya, with $\rho$ value 0,000 . The conclusion, Murattal is effective to relieve dysmenorrhea. There is a need of developing other non-pharmacology interventions to relive dysmenorrhea.
\end{abstract}

Keywords: Dysmenorrhea, Murattal, Pain

\section{INTRODUCTION}

Dysmenorrhea is pain that occurs during menstruation period. Menstruation is an interesting topic because normal women have monthly period of menstruation (Laila N, 2011; Prihatama, 2013). Sari’s research (2013) found that around 15\% American teenagers were suffered heavy dysmenorrhea and around $60 \%$ did not attend school during that time. The pain characteristic were ebb, flow, and continuing cramp. According to Long (1996, in Mubarak 2008) that is a subjectively discomfort feeling that unexplained and cannot be evaluated (Laila N, 2011; Purwaningsih, 2010; Mubarak, 2008).

The impact of dysmenorrhea were disturbing or impairing women activities especially teenagers. Other symptoms of dysmenorrhea were queasiness, vomiting, diarrhea cramps and colic abdomen. In addition, Lestari stated (2013) that around 70$90 \%$ of menstruation pain occurs in teenagers and can be impacted to emotional conflicts, tensions, and heavy anxiety. Prawirohardjo (2009, in Malinda 2013) said menstrual pain can be solved by using pharmacological or non-pharmacological therapy. One way to deal 
with dysmenorrhea is applying non-pharmacological therapy such as listening Murattal. Murattal is reading the surah in Muslim holy book: Al-Qur'an.

Al-Qur'an is a holy book for Muslim. Muslim is a term for a person who believed of Islam. Listening to someone who read the holy Quran would effected Muslims' peacefulness (Rilla, 2014). Dysmenorrhea is affected psychological changes such as anxiety, difficult to focus in study, and disturbing study process. It needs to be handled immediately because it might be affected their physic and physiology (Azizah, 2015; Yuliatun, 2013; Retnoningrum 2015). The preliminary study found that young women did some action to cope with dysmenorrhea, such as take a rest, take medicines, warm compress, drink warm water, and sometimes they're crying because the intensity of resistible pain. None of women listen to music or others including Murattal to deal with dysmenorrhea. This study is aimed to find the effect of listening: Murattal in relieving dysmenorrhea for female student.

\section{METHODS}

This research was a quantitative study using quasi experiment method, pre-post-test with control group design (Notoatmodjo, 2011). The population was all female students year 8 at SMPN 12 Tasikmalaya which had dysmenorrhea history during April to May. The samples were chosen using purposive sampling technique. There were 15 respondents in the intervention group and others 15 respondents as the control group. The instrument was an observation sheet with a numeric scale. The scale names the Numeric Rating Scale (NRS) to measure the level of pain from 0-10. The Murattal of Ar-Rahman listened by respondents using researcher's mobile phone and connected to the earpieces with criteria: frequency $12-15 \mathrm{~Hz}$, medium volume, in a comfortable room for 15 minutes. 


\section{RESULTS}

The study findings present in table 1, 2, 3 and 4. Table 1 present the dysmenorrhea pain level before the Murattal Therapy intervention.

Table 1 Frequency distribution of The Level of Pain before The Intervention

Mild pain Level of pain

Moderate pain

Total

$\begin{array}{cc}\mathbf{n} & \text { \% } \\ 6 & 40 \\ 9 & 60 \\ 15 & 100\end{array}$

Table 1 shows that the majority of respondent had moderate pain before the intervention, and $40 \%(\mathrm{n}=6)$ had mild pain.

The level of pain in female students with dysmenorrhea after the Murattal therapy intervention describe in table 2.

Table 2 Frequency Distribution of The Level Of Pain after The Intervention

Mild pain

Level of pain

Moderate pain

Total

\begin{tabular}{cc}
$\mathbf{n}$ & \% \\
\hline 13 & 86,7 \\
2 & 13,3 \\
15 & 100 \\
\hline
\end{tabular}

Table 2 presents that the majority of respondents had mild pain $(86.7 \%)$ after listening Murattal of Surah Ar-Rahman, only 2 female students suffered moderate pain.

The average of dysmenorrhea before and after the Murattal Therapy presents in table 3 .

Table 3 The average of dysmenorrhea before and after Murattal Therapy

$\begin{array}{lllll}\begin{array}{l}\text { Murattal } \\ \text { Therapy } \\ \text { Intervention }\end{array} & \text { Mean } & \text { SD } & \text { Min-Max } & \text { 95\% CI } \\ \end{array}$




\begin{tabular}{lcccc}
\hline Before & 3,67 & 1,345 & $2-6$ & $2,92-4,41$ \\
After & 1,93 &, 100 & $1-4$ & $1,32-2,54$ \\
\hline
\end{tabular}

Table 3 shows that the average of pain before Murattal Therapy was 3,67 and after was 1,93 with standard deviation before therapy 1,345 and after 1,00 , minimum pain before therapy 2 and after 1. Meanwhile maximum pain before therapy was 6 and after 4 with CI 95\% before therapy 2,92-4,41 after 1,32- 2,45.

Table 4 The Effect of Murattal Therapy to Relieve Dysmenorrhea

\begin{tabular}{lccccc}
\hline \multicolumn{1}{c}{ Pain Scale } & Mean & N & SD & p-value & 95\% CI \\
\cline { 2 - 5 } $\begin{array}{l}\text { Before and after } \\
\text { Murattal Therapy }\end{array}$ & 1,733 & 15 & 0,704 & 0,000 & $1,344-2,123$ \\
\hline
\end{tabular}

Table 4 shows the differences of mean before and after Murattal therapy to dysmenorrhea 1,733 with standard deviation 0,70 and CI result $95 \%$ with $1,344-2,123$. The results of statistical test obtained value $\rho=0,000$. It can be concluded that there was an effect of Murattal Therapy to relieve dysmenorrhea to female students of SMPN 12 Tasikmalaya.

\section{DISCUSSION}

The level of dysmenorrhea pain of female students in SMPN 12 Tasikmalaya before the Murattal Therapy were mild pain $40 \%$ and moderate pain $60 \%$. The Murattal therapy used Surah Ar-Rahman. This surah content reminder about the finest name of Allah SWT as the Most Merciful. It's also reminded us that we only human who have obligation to worship Allah SWT. It also would motivate us to put more spirit to worship Allah SWT. Furthermore Surah Ar-Rahman having benefits to relieve pain and also as the primary instrument to increase the quality of relaxing, diverting attention, reducing anxiety, tension as well as lowering emotion. 
After the Murattal Therapy intervention, the level of qpain decreased significantly. The majority of respondent had mild pain $(86,7 \%)$ and $13,3 \%$ of them had moderate average pain. Surah Ar-Rahman had been affecting to relieve dysmenorrhea pain. It also has an effect of relaxation against the body, because constant, regular, and stabile rhythm, also low tune. Moreover Murattal can also lowering stress hormone, activating endorphin hormone naturally, increase relax feeling, lowering anxiety and tension, lowering blood pressure and also slowing down respiratory and brain wave activity (Muhidin, 2016). The result of this research also showed the average before treated by Murattal Therapy 3,67 and after treated 1,93 . Those are based on statistic test result valued $=\rho=0,000$, so it can be concluded that there is an effect between Murattal Therapy to relieve dysmenorrhea pain to female students of SMPN 12 Tasikmalaya.

The majority of teenagers usually are prefer to listen to the music than Murattal. It can be seen from the average of pain level after music therapy. Many factors influence teenagers' interest of modern music than Murattal such as environment, family support, and the era of technology. Nevertheless, Murattal therapy by using Surah Ar-Rahman is motivating listeners in improving their worship Allah SWT, because adolescent lack of understanding and learning Islam. Murattal therapy is effective to relieve dysmenorrhea pain. The affectivity of Murattal Therapy can be seen by decreasing the average of pain after Murattal therapy. This research was focus on teenagers' respondents that would be different result if this method applies to adult. There is a need of more researches about this topic as the study is limited.

\section{CONCLUSION}


The average of dysmenorrhea pain before Murattal Therapy was 3,67 and the average dysmenorrhea pain after Murattal Therapy was 1,93. There is an effect from musical therapy to relieve dysmenorrhea pain to female students of SMPN 12 Tasikmalaya with result $\rho$ value 0,000 .

\section{REFFERENCE}

Adriansyah. (2014). Pengaruh Terapi Musik Klasik Dan Murattal Terhadap Penurunan Tingkat Stres Mahasiswa S1 Semester AkhirUniversitas Muhammadiyah Surakarta. http://www.eprints.ums.ac.id/30817/17/9rr._naskah_publikasi.pdf.

Anisa M. (2015). The Effect Of Exercises On Primary Dysmenorrhea. http://www.lib.ui.ac.id.

Arikunto. (2010). Prosedur Penelitian Suatu Pendekatan Praktik. Jakarta: PT Rineka CiptA.

Astutik. (2013). Pengaruh Pemberian Terapi Musik Dan Back Exercise Terhadap Penurunan Tingkat Nyeri Dysmenorrhea Primer. http://www. Eprints. Ums.ac.id.

Aulia. (2012). Serangan Penyakit-Penyakit Khas Wanita Paling Sering Terjadi. Yogyakarta: Buku Biru.

Azizah N. (2015). Teknik Relaksasi Nafas dalam dan Terapi Musik Sebagai Upaya Penurunan Intensitas Nyeri Haid (Dysmenorrhea). http://www Jurnal. Unimus. co.id.

Barbara, Koizer .(2010). Buku Ajar Fundamental Keperawatan: Konsep, Proses \& Praktik.

BlackJ. (2014). Keperawatan Medikal Bedah, Manajement Klinis Untuk Hasil Yang Diharapkan Edisi 8 Buku 1. Elsiver : Singapura dicetak Jakarta: Selemba Medika.

Bobak. (2012). Buku Ajar Keperawatan Maternitas Edisi 4. Jakarta: EGC.

Crowin J. (2009). Buku Saku Patofisiologi. Edisi revisi 3. Jakarta: EGC.

Desminore Di SMAN Kecematan Curup .http://www.lib.ui.ac.id.

Fajar ,Ibnu, dkk. (2009). Statistika untuk Praktisi Kesehatan. Yogyakarta: Graha Ilmu Februanti. (2017). Pengetahuan Remaja Putri Tentang Penanganan Dismenore Di SMPN 9. 
Inisiasi Menyusu Dini Dan Durasi Menyusui Bayi Http://www.epirnts.undip.ac.id/43252/2/14/._BAB_II.

Insani.(2014). Pengaruh Alunan Murattal Terhadap Intensitas Nyeri Dismenore Orimer Pada Siswi Madrasah Mu'allimat Muhhamadiyah Yogyakarta. http://opac.unisayogya.ac.id.

Jaury.(2014). Gambaran Nilai Vas (Visual Analogue Scale) Pasca Bedah Seksio Sesar Pada Penderita Yang Diberikan Tramadol. http://www.download.portalgaruda.org/article.

Laila N. (2011). Buku Pintar Menstruasi + Solusi Atasi Segala Keluhannya Mengupas Tuntas Berbagai Hal Terkait Menstruasi Dan Segala Permasalahannya. Yogyakarta: Buku Biru.

Lina. (2010). Pengaruh terapi musik terhadap tingkat nyeri persalinan pada klien intrapartum kala I. http://www.opac.unisayogya.ac.id. Diakses : 19 Maret 2017, Pukul 17.30 WIB Lestari. (2013). Pengaruh Dismenorea Pada Remaja.http://ejurnal.undiksha.ac.id.

Marlinda. (2013). Pengaruh Senam Dismenore Terhadap Penurunan Dismenore Pada Remaja Putri Di Desa Sidoharjo Kecamatan Pati. Jurnal Keperawatan Maternitas. Vol.1. No.2. http://www.jurnal.unimus.ac.id.

Maryunani. (2011). Senam Hamil, Senam nifas, dan Terapi Musik. Jakarta: TIM.

Mitayani. (2011). Asuhan Keperawatan Maternitas. Jakarta : Selemba Medika.

Mubarak. (2008). Buku Ajar Kebutuhan Dasar Manusia Teori Dan Aplikasi Dalam Peraktik. Jakarta: EGC.

Muhidin. (2016). Pengaruh Murattal AR-Rahman terhadap Nyeri Desminore Pada Remaja. http://www.akpermadiun.ac.id/web/file/jurnal/Jurnal\%202016-6.

Notoatmodjo,Soekidjo. (2010). Metedologi Penelitian Kesehatan. Jakarta : Rineka Cipta.

Ningsih R. (2011). Efektifitas Paket Pereda Terhadap Intensitas Nyeri Pada Remaja Dengan

Nuryaningsih. (2013). Pengaruh Senam Dismenore Terhadap Tingkat Nyeri Haid Pada Menarche Remaja Putri Di Mts Tarbiyatul Mubtadiin Wilalung Kecamatan Gajah Kabupaten Demak. http://www.jurma.unimus.ac.id.

Potter \& Perry. (2006). Buku Ajar Fundamental Keperawatan Konsep, proses, dan Peraktik, Ed. 4, Vol. 2. Jakarta: EGC 
Prasetia. (2015). Pengaruh Terapi Musik Klasik (Beethoven)Terhadap Tingkat Nyeri Haid (Dismenorea)Pada Remaja Putri Kelas Ii Di Mts Ngemplak Sleman Yogyakarta. http://www.unisayogya.ac.id.

Prihartama. (2013). Hubungan Antara Stress Dan Desminore Pada Siswi Kelas Tiga SMAN 2 Ngawi. http://eprints.ums.ac.id. Diakses : 19 Maret 2017, Pukul 21.00 WIB

Purwaningsih. (2010). Asuhan Keperawatan Maternitas. Yogyakarta: Nuha Medika.

Purwanto. (2013). Herbal dan keperawatan komplementer (Teori, Praktik, Hukum dalam Asuhan Keperawatan). Yogyakarta: Nuha Medika

Retnoningrum. (2015). Hubungan antara riwayat dismenorea keluarga dengan kejadian dismenorea berat pada remaja putri di SMP Islam Terpadu Miftahul Ulum Ungaran. http://www. Perpusnwu .web.id/ karyailmiah/ document / 3696.pdf.

Rilla.(2014). Terapi Murattal Efektif Menurunkan Tingkat Nyeri Dibanding Terapi Musik Pada Pasien Pascabedah. Jurnal Keperawatan Indonesia vol.17.http://jki.ui.ac.id. Diakses : 7 Juni 2017 Pukul 15.00 WIB.

Riyanto. (2009). Pengolahan dan Analisis Data Kesehatan (Dilengkapi Uji Validitas dan Reliabilitas serta apalikasi program SPSS). Yogyakarta: Nuha Medika.

Rohani. (2017). Desminore. http://www.thebook.net/ps/proposal.tentang desminore.

Sari N. (2006). Musik dan Kecerdasan Otak Bayi. Bogor : KH. Kharisma Buka Aksara

Sari P. (2013). Perbedaan Terapi Musik Klasik Mozart Dengan Terapi Musik Kesukaan Terhadap Intensitas Nyeri Haid Pada Remaja Putri Di Sma Negeri 5 Denpasar Tahun 2012. http://www.ojs.unud.ac.id.

Sujarweni.(2012). SPSS Untuk Paramedis. Yogyakarta: Gava Medika

Sulistiyaningsih. (2011).Metodelogi Penelitian Kebidaan: KuantitatifKualitatif. Ed 7,Vol.1. Jakarta: EGC.

Sulistiyorini. (2014). Efektifitas Terapi Musik Klasik (Mozart) Terhadap Waktu Keberhasilan. Yogyakarta: Graha Ilmu

Supardi. (2013). Buku Ajar Metodelogi Riset Keperawatan. Jakarta: TIM.

Suparnanto J.(2009). Statistik Teori dan Aplikasi ed 7. Jakarta : Erlangga

Susanti. (2014). Hubungan Stress Dengan Kejadian Desminorea pada Mahasiswi DIII Kebidanan Semester 2 disetikes aisyiyah Yogyakarta Tahun 2014. http://www.opac.unisayogya.ac.id.

Tasikmalaya. Jurnal Kesehatan Bakti Tunas Husada. http://www. ejurnal.stikes-bth.ac.id. 
Yuliatun. (2013). Pengaruh Terapi Musik Klasik Terhadap Intensitas Dismenorea Primer Pada Mahasiswi Psik-A 2006-2007 Fkub Malang http://www.Jlk.ub.ac.id. 